\title{
Production and Nutritional Quality of High Yielding Fodders in the Coastal Areas for Ruminants
}

\author{
M. Z. Rahman and M. A. I. Talukder* \\ Bangladesh Livestock Research Institute, Savar, Dhaka-1341 \\ *Corresponding author and Email: talukder1963@yahoo.com
}

Received: 28 May $2014 \quad$ Accepted: 06 June 2015

\begin{abstract}
The experiment was conducted to study the production and nutritional values of high yielding fodders by the goat farmers in Kobirhat and Subornochar upazilas of Noakhali District. The yields of high yielding forages had significant differences among the species. The average higher biomass were obtained from Napier-hybrid (34), Napier-aerosa (20), Napier-bazra (17.33) and Splendida (19). The Andropogon and Signal fodder had similar yields of $12.67 \& 13.67 \mathrm{t} / \mathrm{ha} / \mathrm{cut}$. There was a significant $(\mathrm{P}<0.05)$ variations in the DM contents among the forages. The DM content $(\%)$ of Napier varieties ranged from 19.60 to 22.30, and highest value was found in Ruzi (27.90). A non-significant $(\mathrm{P}<0.05)$ differences were observed in the CP content (\%) among the Napier and Splendida varieties. There was no significant difference in metabolizable energy content $(\mathrm{MJ} / \mathrm{kgDM})$ among the forages. The cultivation of high yielding fodders e.g. Napier hybrid, Napier aerosa, Napier bazra and Splendida may be practiced in the saline areas of Noakhali for high productivity of ruminants.
\end{abstract}

Keywords: Napier, splendida, crude protein, metabolizable energy

\section{Introduction}

The coastal saline soils in Bangladesh occupy an area of 1.5 million hectares, of which about 1.0 million ha is cultivable (BARC, 1997). The area includes parts of 12 districts out of 64 namely Khulna, Satkhira, Borguna, Perojpur, Cox's Bazar, Bagerjat, Patuakhali, Bhola, Noakhali, Feni, Laxmipur and Chittagong. FallowT.Aman-Fallow is the predominant cropping pattern in this saline area. Although double cropping (Fallow-T. Aman - Rabi) is practiced in some areas, triple cropping (T. Aus-T. AmanRabi) is rare. This soil is highly saline, organic matter and nitrogen deficient, and there is lack of sweet water in the dry season, but has adequate phosphorus. There is a great potential of growing salt tolerant forages in these vast fallow and saline soils where other crops cannot be grown. The yields of perennial grasses per year are higher in this area due to frequent cuttings in 4045 days interval (Islam et al., 2001).

Napier (Pennisetum purpureum) is a perennial grass grown widely as a fodder crop and feed for cut and carry zero grazing dairy systems (Bayer, 1990) and constitutes up to $80 \%$ of forage for smallholder dairy farms (Staal et al., 1987). It is the forage of choice not only in the tropics but also worldwide (Hanna et al., 2004) due to its desirable traits such as tolerance to drought in wide range of soil conditions, high photosynthetic and water use efficiency (Anderson et al., 2008). 
While much attention has been directed towards research for improving the productivity of major cereal crops, there has been comparatively little effort to improve Napier grass-an important forage crop that has been grown over centuries and currently enjoys a multiplicity of uses besides conventional animal consumption (Jaradat, 2010).

Although biomass yield is the single most important criteria to select a fodder, there are other criteria like nitrogen and energy content which are very important to be considered in selecting a fodder. The nutritive value of different fodder within the same plant may vary and the animals have the opportunity to select succulent parts of the fodder in preference to others. Among non-legume perennial fodder, the yield potential of Napier (Pennisetum purpureum) grass was higher than others in early establishment of native climatic condition of Bangladesh (Kibria et al., 1991). At present, five varieties of Napier grasses (bazra, aerosha, hybrid, pusha and India-17) have been cultivated and cuttings have also been distributed among the interested farmers who want to cultivate Napier. Such study may be valuable for the coastal farmers to select suitable fodder varieties to improve their livestock. An experiment was therefore conducted to study the production and nutritional values of high yielding fodders by the goat farmers in saline areas of Kobirhat and Subornochar upazilas in Noakhali.

\section{Materials and Methods}

\subsection{Selection of grasses}

Coastal locations are characterized by slightly, moderately and highly saline. Ten perennial grasses were cultivated in May 2010 at three sites of Noakhali district to investigate the yield potential of the grasses in coastal areas using a randomized complete block design. The areas are Southern Agro Trade (salinity 5-6 dS/m), Kobirhat upazila (salinity 6-7 dS/m) and Subornochar upazila (salinity 8-10 dS/m). Twenty farmers were selected under each site.
During land preparation fermented cow dung was applied @ of $35 \mathrm{~kg} /$ decimal.

The grasses were propagated by stem cutting method. Line to line and plant to plant distances were 70 and $35 \mathrm{~cm}$, respectively. Weeding and irrigation were done when necessary. During land preparation, Phosphate (TSP) and MP fertilizer were applied @150 and $125 \mathrm{~kg} / \mathrm{ha}$, respectively. Urea@ $@ 50$ kg was applied 20-30 days after transplanting followed by $50 \mathrm{~kg}$ urea was applied after 10-12 days of each cutting. The perennial grasses were Napier-bazra, Napieraerosa \& Napier -hybrid (Pennisetum purpureum), Andropogon (Andropogon gyanus), Splendida (Setaria splendida), Ruzi (Brachiaria ruziziensis), Guinea (Panicum maximum), Signal (Brachiaria decumbens), Para (Brachiaria mutica) and German (Echinoclora crousgalli).

\subsection{Cutting interval and cutting number} Grasses were harvested at a regular interval at 40-45 days after each cutting, while first cut was made 55-60 days after the establishment. The similar intervals for each grass were nearly 10 cutting number (harvests) commencing from the start of the experiment.

\subsection{Chemical analysis of samples}

The forage samples were subjected to chemical analysis for the determination of the dry matter $(\mathrm{DM})$, organic matter (OM), crude protein (CP) and ash following the Methods of AOAC (1995). The acid detergent fibre (ADF) was determined according to Goering and Van Soest (1970). All the samples were analyzed in duplicate and the mean values were recorded. According to ARC (1980), DOMD $(\%)=75.73-0.269 \times \mathrm{ADF} \%, \mathrm{ME}$ $(\mathrm{MJ} / \mathrm{kg} \mathrm{DM})=\mathrm{DOMD} \times 0.15$.

\subsection{Statistical analysis}

The statistical analysis was done using 'SPSS $11.5^{\prime}$ statistical programme to compute analysis of variance (ANOVA) for randomized complete block design (RCBD). Differences among the treatment means were determined by Duncan's Multiple range Test (Duncan, 1955). 


\section{Results and Discussion}

\subsection{Selection of salt tolerant grasses}

The height biomass yield ( $\mathrm{t} / \mathrm{ha} / \mathrm{cut}$ ) obtained from Napier varieties (35.12) and Splendida (20.03), whilst the lowest was from Ruzi (6.01), which was about one-sixth of the amount of the highest (Table 1). Therefore, Ruzi cannot be selected under any circumstances. In general, grass yield ( $\mathrm{t} / \mathrm{ha} /$ cut) was higher in the saline areas of Subarnachar followed by Southern Agro Trade of Subornochar and Kobirhat upazila. However it is clear, that four grasses namely Napier bazra, Napier aerosa, Napier hybrid and Splendida could be grown in saline areas to get higher biomass yield compared to other grasses included in this trial (Figure 1).

Biomass yield ( $\mathrm{t} / \mathrm{ha} /$ year) was highest for Napier hybrid (204) followed by Napier aerosa (120), Napier bazra (104) and Splendida (114), whereas yield was the lowest for Ruzi (56) (Figure 2).
These grasses may be screened for saline areas. Similar yield was found in the plain land areas of BLRI (Islam et al., 2001). It seems that Napier and Splendida may be introduced in all location of studied areas.

\subsection{Biomass yield}

The average higher biomass (t/ha/cut) was obtained from Napier hybrid (34), Napier aerosa (20), Napier bazra (17.33) and Splendida (19) and the lowest was from Ruzi (8). Andropogon and Signal had similar yield (Figure 1). These results indicate that Napier varieties and Splendida always have higher biomass yield while Ruzi had the lowest. Kibria et al. (1993) stated that among non-legume perennial fodders, Napier yield was higher than others in native climatic condition of Bangladesh. Sarker et al. (2013) reported that the biomass yield of Napier hybrid in the areas of Savar, Dhaka was 48.21 t/ha/cut.

Table 1. Effect of types of perennial grasses on biomass yield (t/ha/cut)

\begin{tabular}{|c|c|c|c|c|c|}
\hline \multirow[b]{2}{*}{$\begin{array}{l}\text { SL. } \\
\text { No. }\end{array}$} & \multirow[b]{2}{*}{ Fodder species } & \multicolumn{3}{|c|}{ Fodder Yield (t/ha/cut) } & \multirow{2}{*}{$\begin{array}{l}\text { Level of } \\
\text { sig. }\end{array}$} \\
\hline & & $\begin{array}{c}\text { Southern Agro Trade } \\
\text { Subornochar }\end{array}$ & Kobirhat upazila & $\begin{array}{l}\text { Subornochar } \\
\text { upazila }\end{array}$ & \\
\hline 1 & $\begin{array}{l}\text { Napier bazra } \\
\text { (Pennisetum purpureum) }\end{array}$ & $18.11 \pm 0.91$ & $16.12 \pm 0.87$ & $18.10 \pm 0.96$ & NS \\
\hline 2 & $\begin{array}{l}\text { Napier aerosa } \\
\text { (Pennisetum purpureum) }\end{array}$ & $20.09 \pm 1.02$ & $19.08 \pm 0.98$ & $21.06 \pm 1.21$ & NS \\
\hline 3 & $\begin{array}{l}\text { Napier hybrid } \\
\text { (Pennisetum purpureum) }\end{array}$ & $34.12 \pm 1.23$ & $33.11 \pm 1.32$ & $35.12 \pm 0.92$ & NS \\
\hline 4 & $\begin{array}{l}\text { Andropogon } \\
\text { (Andropogon gyanus) }\end{array}$ & $13.02 \pm 0.11$ & $11.06 \pm 0.69$ & $14.03 \pm 0.57$ & NS \\
\hline 5 & $\begin{array}{l}\text { Splendida } \\
\text { (Setaria splendida) }\end{array}$ & $19.09 \pm 1.01$ & $18.05 \pm 1.11$ & $20.03 \pm 0.86$ & NS \\
\hline 6 & Ruzi (Brachiaria ruziziensis) & $8.02^{\mathrm{b}} \pm 0.85$ & $6.01^{\mathrm{a}} \pm 0.99$ & $10.02^{\mathrm{b}} \pm 0.75$ & $*$ \\
\hline 7 & Guinea (Panicum maximum) & $12.05^{\mathrm{b}} \pm 1.11$ & $9.04^{\mathrm{a}} \pm 0.68$ & $13.06^{\mathrm{b}} \pm 0.75$ & $*$ \\
\hline 8 & $\begin{array}{l}\text { Signal (Brachiaria } \\
\text { decumbens) }\end{array}$ & $14.08 \pm 0.88$ & $13.06 \pm 0.63$ & $14.10 \pm 0.84$ & NS \\
\hline 9 & Para (Brachiaria mutica) & $12.05 \pm 0.77$ & $11.12 \pm 1.02$ & $12.11 \pm 1.01$ & NS \\
\hline 10 & $\begin{array}{l}\text { German (Echinoclora } \\
\text { crousgalli) }\end{array}$ & $11.13 \pm 0.98$ & $9.09 \pm 0.89$ & $10.68 \pm 0.76$ & NS \\
\hline
\end{tabular}

\footnotetext{
${ }^{\mathrm{ab}}$ Mean values in a row with different superscripts differ significantly, NS= Not significant, $* \mathrm{P}<0.05$
} 


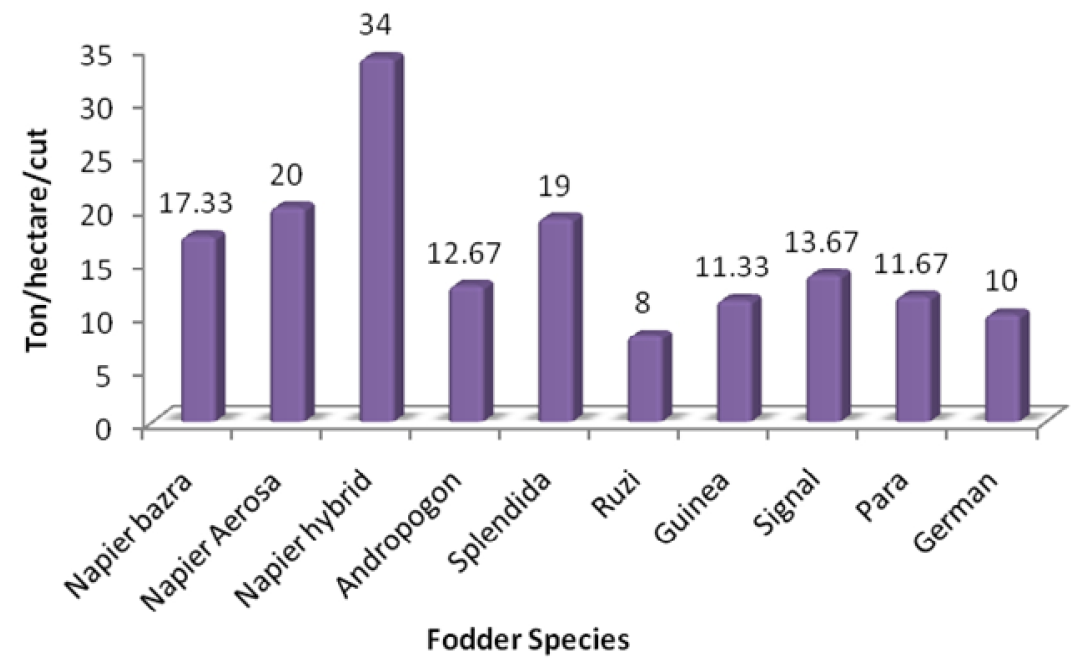

Figure 1. Effect of types of grasses on biomass yield of diffirent types of fodder species per cut

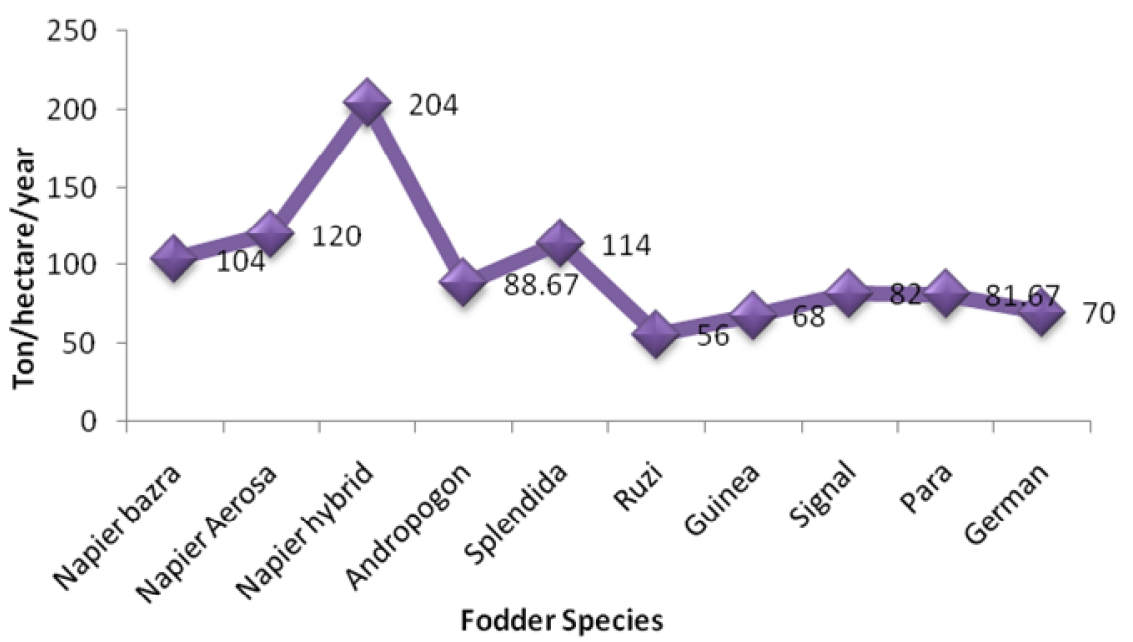

Figure 2. Effect of types of grasses on biomass yield of fodder species per year 
Table 2. Effect of types of perennial grasses on chemical composition

\begin{tabular}{|c|c|c|c|c|c|c|}
\hline \multirow{2}{*}{$\begin{array}{l}\text { SL. } \\
\text { No. }\end{array}$} & \multirow{2}{*}{ Fodder species } & \multirow{2}{*}{$\begin{array}{c}\mathrm{DM} \\
(\mathrm{g} / 100 \mathrm{~g} \text { fresh matter })\end{array}$} & \multicolumn{4}{|c|}{$\mathrm{g} / 100 \mathrm{~g} \mathrm{DM}$} \\
\hline & & & Ash & $\mathrm{OM}$ & $\mathrm{CP}$ & $\mathrm{ADF}$ \\
\hline 1 & Napier bazra (Pennisetum purpureum) & $19.60^{\mathrm{a}} \pm 1.22$ & $7.90^{\mathrm{b}} \pm 1.56$ & $92.10 \pm 2.89$ & $7.80^{b} \pm 0.45$ & $38.80^{b} \pm 3.89$ \\
\hline 2 & Napier aerosa (Pennisetum purpureum) & $21.40^{\mathrm{a}} \pm 1.35$ & $10.30^{c} \pm 1.11$ & $89.70 \pm 3.11$ & $7.50^{\mathrm{b}} \pm 0.56$ & $25.80^{\mathrm{a}} \pm 4.21$ \\
\hline 3 & Napier hybrid (Pennisetum purpureum) & $22.30^{\mathrm{ab}} \pm 1.51$ & $10.40^{\mathrm{c}} \pm 1.56$ & $89.60 \pm 2.33$ & $7.90^{\mathrm{b}} \pm 0.35$ & $26.50^{\mathrm{a}} \pm 3.56$ \\
\hline 4 & Andropogon (Andropogon gyanus) & $26.70^{\mathrm{b}} \pm 1.32$ & $5.80^{\mathrm{a}} \pm 0.92$ & $94.20 \pm 3.33$ & $5.90^{\mathrm{a}} \pm 0.69$ & $40.90^{\mathrm{b}} \pm 4.11$ \\
\hline 5 & Splendida (Setaria splendida) & $24.60^{\mathrm{b}} \pm 1.46$ & $7.80^{\mathrm{b}} \pm 0.91$ & $92.20 \pm 1.97$ & $7.20^{\mathrm{b}} \pm 0.89$ & $27.50^{\mathrm{a}} \pm 3.33$ \\
\hline 6 & Ruzi (Brachiaria ruziziensis) & $27.90^{\mathrm{b}} \pm 1.67$ & $6.20^{\mathrm{a}} \pm 0.88$ & $93.80 \pm 2.56$ & $8.90^{\mathrm{b}} \pm 0.87$ & $42.90^{\mathrm{bc}} \pm 4.63$ \\
\hline 7 & Guinea (Panicum maximum) & $24.30^{\mathrm{b}} \pm 0.96$ & $7.50^{\mathrm{b}} \pm 0.75$ & $92.50 \pm 2.41$ & $8.20^{\mathrm{b}} \pm 0.59$ & $31.80^{\mathrm{a}} \pm 2.96$ \\
\hline 8 & Signal (Brachiaria decumbens) & $27.80^{\mathrm{b}} \pm 1.78$ & $6.60^{\mathrm{a}} \pm .071$ & $93.40 \pm 3.76$ & $6.80^{\mathrm{b}} \pm 0.63$ & $39.40^{\mathrm{b}} \pm 4.23$ \\
\hline 9 & Para (Brachiaria mutica) & $26.70^{\mathrm{b}} \pm 2.12$ & $5.30^{\mathrm{a}} \pm 0.44$ & $94.70 \pm 2.44$ & $7.40^{\mathrm{b}} \pm 0.87$ & $48.70^{c} \pm 4.68$ \\
\hline \multirow[t]{2}{*}{10} & German (Echinoclora crousgalli) & $24.50^{\mathrm{b}} \pm 1.96$ & $5.40^{\mathrm{a}} \pm 0.23$ & $94.60 \pm 2.99$ & $9.20^{\mathrm{b}} \pm 0.96$ & $47.50^{\mathrm{c}} \pm 4.89$ \\
\hline & Level of significance & $*$ & $*$ & NS & $*$ & $*$ \\
\hline
\end{tabular}

${ }^{\mathrm{abc}}$ Mean values in a row with different superscripts differ significantly, NS= Not significant, $* \mathrm{P}<0.05$, 
Table 3. Effect of types of perennial grasses on metabolizable energy content $(\mathrm{MJ} / \mathrm{kgDM})$

\begin{tabular}{clc}
\hline $\begin{array}{c}\text { SL. } \\
\text { No. }\end{array}$ & \multicolumn{1}{c}{ Fodder species } & $\begin{array}{c}\text { Metabolizable Energy content } \\
\text { (MJ/kgDM) }\end{array}$ \\
\hline 1 & Napier - bazra (Pennisetum purpureum) & $9.8 \pm 0.86$ \\
2 & Napier-aerosa (Pennisetum purpureum) & $10.3 \pm 0.83$ \\
3 & Napier-hybrid (Pennisetum purpureum) & $10.2 \pm 0.76$ \\
4 & Andropogon (Andropogon gyanus) & $9.7 \pm 0.88$ \\
5 & Splendida (Setaria splendida) & $10.2 \pm 0.75$ \\
6 & Ruzi (Brachiaria ruziziensis) & $9.6 \pm 0.98$ \\
7 & Guinea (Panicum maximum) & $10.1 \pm 1.05$ \\
8 & Signal (Brachiaria decumbens) & $9.7 \pm 0.95$ \\
9 & Para (Brachiaria mutica) & $9.4 \pm 0.85$ \\
10 & German (Echinocloa crous-galli) & $9.4 \pm 0.87$ \\
\hline & Level of significance & $\mathrm{NS}$ \\
\hline
\end{tabular}

\subsection{Nutritive value of grasses}

Table 2 shows that there were significant $((\mathrm{p}<0.05)$ differences in the DM, Ash, CP and ADF contents of the grasses. The DM contents of Napier varieties were lower than those of other forages. The DM content of Napier varieties ranged from 19.60 to 22.30 and higher in Ruzi (27.90). Ruzi and Signal contained higher DM than Andropogon, Para, German, Guinea and Splendida. Napier hybrid had the highest Ash content but had lower ADF. Para had the lowest Ash content but highest ADF content. There were no significant differences in respect of $\mathrm{CP}$ contents among the forages, except Andropogon. The high productive Napier varieties contained $\mathrm{CP}(\%)$ ranging from 7.50 to 7.90 and Splendida contained CP of 7.2. The ADF content of Napier bazar was significantly $(p<0.05)$ higher than those of Napier aerosa, Napier hybrid and Splendida. These finding agreed with that reported by Islam et al. (2001). The use of forage has focused the attention of many researchers, due to the fact that these feed resources are perennial (Singh, 1995; Leng, 1997) and particularly appropriate for small ruminants (Van Eys et al., 1986; Robertson, 1988; Chen et al., 1992; Norton, 1994; Kaitho, 1997).
The metabolizable energy content (MJ/kgDM) was similar in all the forages ranging from 9.4 to 10.3 (Table 3 ). Therefore, the biomass yield was the most important criterion for selecting forages and was not only the nutritive value, particularly ME.

\section{Conclusions}

Napier-hybrid, Napier-aerosa, Napier-bazra and Splendida yielded higher biomass than other varieties. One of the most important characteristics of these grasses is that they can be grown in saline areas. Another advantage of cultivating these perennial grasses is that once established they can supply fodder for about five years and cutting can be done in every 40-45 days. The nutritive values in terms DM, OM, CP, ADF and Ash contents were good in the fodders. The highest fodder production was found in Napier hybrid, followed by Napier aerosa, Napier bazra and Splendida. The cultivation of high yielding fodders e.g., Napier hybrid, Napier aerosa, Napier bazra and Splendida may be practiced in the saline areas of Noakhali for high productivity of ruminants. 


\section{References}

AOAC. 1995. Official Methods of Analysis. $\left(16^{\text {th }}\right.$ edition), Association of Official Analytical Chemist. Washington D.C.

Anderson, W. F, Dien, B. S., Bradson, S. K., Peterson, J. D. 2008. Assessment of Bermuda grass and bunch grasses as feed stocks for conversion to ethanol. Applied Biochemistry and Biotechnology, 145: 1321.

ARC. 1980. Nutrient Requirements Farm Animals. Commonwealth Agricultural Bureau, Slough, UK.

BARC. 1997. Fertilizer recommendation guide 1997. Bangladesh Agricultural Research Council, Farmgate, Dhaka.

Bayer, W. 1990. Napier grass- a promising fodder for smallholder livstock production in the tropics. Plant Research Development, 31: 103-111.

Chen, C. P., Halim, R. A. and Chin, F. Y. 1992. Fodder trees and fodder shrubs in range and farming systems of the Asian and Pacific region. In: Legume trees and other fodder trees as protein sources for Livestock (A. Speedy and P. L. Pugliese, editors). FAO Animal Production and Health Paper No. 102, 11-22 pp.

Duncan, D. B. 1955. Multiple Range and Multiple F-tests. Biometrics, 11: 1-42.

Goering, H. G and Van Soest, P. J. 1970. Forage fiber analysis. ARD. USDA. Washington, DC. Agriculture Handbook, no. 379,20 pp.

Hanna, W. W., Chaparro, C. J., Mathews, B. W. Burns, J. C, Solenberger, L. E. Carpenter, J. R. 2004. Perenial pennisetums. In: LE, Burson B. L., Sollenberger L. E., Editors. Warm-season (C4) grasses. Madison, American Society of Agronomy: Monograph series, 34: 503-535.
Islam, M. R., Chowdhury, S. A., Hasanuzzaman, M., Huque, K. H. and Jalil, M. A. 2001. Report on Production performance of different high biomass yielding grasses as affected by salinity and establishment of a germplasm bank. Animal Production Research Division, BLRI, Savar, Dhaka1341.

Jaradat, A. A. 2010. Genetic resources of energy crops: biological systems to combat climate change. Australian Journal of Crop Science, 4: 309-323.

Kaitho, R. J. 1997. Nutritive value of browses as protein supplement to poor quality roughages. Ph.D thesis. Wageningen University. The Netherlands.

Kibria, S. S., Islam, M. R. and Rahman, M. M. 1993. Feasibility study on the production of different fodder crops in Bangladesh. Bangladesh Journal of Animal Science, 22: 25-33.

Kibria, S. S., Nahar, T., Mia, M. M., Talukder, M. A. I. and Kamal, M. 1991. Performance of Black Bengal goat under stall fed condition. Progress report (19901991). Paper presented at the Livestock Workshop held 22-23 October, BARC, Dhaka.

Leng R. A. 1997. Tree foliage in ruminant nutrition. FAO Animal Production and Health Paper No. 139. Rome, 100 pp.

Norton, B. W. 1994. Tree legumes as dietary supplements for ruminants. In: Forage tree legumes in tropical agriculture (R. C. Gutteridge and P. M. Shelton, editors). CAB International. Wallingford. 202-215 pp.

Robertson, B. M. 1988. The nutritive value of five browse legumes fed as supplements to goats offered a basal rice straw diet. M.Sc. Thesis. University of Queensland. Armidale. 
Sarker, N. R., Bashar, M. K., Alam, M. K. and Huque, K. S. 2013. Biomass yield, morphological characteristics and nutritive value of perennial and winter fodder. Proceedings of the Annual Research Review Workshop 2012-13, BLRI, Savar, Dhaka.

Singh, R. V. 1995. Fodder production from tropical forests in Asia and the Pacific Region. FAO Regional Office for Asia and the Pacific Publication, 1995/16. Bangkok. 65 pp.
Staal, S., Chege, L., Kenyanjui, M., Kimari, A., Lukuyu, B., Nijubi, D, Owango, M., Tanner, J., Throp, W, Wambugu, M. A. 1987. Cross sectional survey of Kimbu district for the identification of target groups of smallholder dairy products. Nairibi, Kenya; KARI/ILRI collaborative project report.

Van Eys, J. E., Mathius, I. W., Pongsapan, P. and Johnson, W. L. 1986. Foliage of the tree legumes gliricidia, leucaena and sesbania as a supplement to napier grass for growing goats. Journal of Agricultural Science, 107: 227-233. 